\title{
所属集団に対する差別・優遇が原因帰属に与える影響
}

\author{
浅井暢子 神戸大学
}

\section{Causal attribution of discrimination and favoritism in a disadvantaged group}

Nobuko Asai (Kobe University)

\begin{abstract}
Two experiments investigated the hypothesis that the need to protect positive self-regards mediates the causal attribution of one's failure to discrimination. Female undergraduates read a scenario in which either the participant herself or another woman (in-group member) took a job interview. The outcome was depicted either as failing (Studies 1 and 2) or passing the interview (Study 2). Participants attributed the failure to gender discrimination only when the interviewers were unanimously sexists. The attribution to discrimination was negatively correlated with the state self-esteem in the social domain. When the protagonist was an in-group member, a moderate level of discrimination was sufficient to elicit the participant's discrimination attribution. For the positive outcome scenario, the participants were more likely to acknowledge the influence of favoritism on their own success than on other's success. These results suggest that the unwillingness for attributing a failure to discrimination functions for the protection of the self-esteem among the members of a disadvantaged group. Implications for the study of coping strategies used by victims of discrimination are discussed.
\end{abstract}

Key words: disadvantaged group, discrimination, favoritism, attribution, self-esteem.

The Japanese Journal of Psychology

2006, Vol. 77, No. 4, pp. 317-324

スティグマを付与された集団に所属する人々は，そ の集団の成員であることだけが理由で，不当な扱いや 評価を受けやすい。こうした否定的評価にどのような 対処方略を用いるかは，スティグマ集団の成員におけ る精神的健康の維持と深くかかわっているだけではな く，社会とスティグマ集団の間の葛藤や交流方略を規 定している。また, 差別・偏見の維持と変容に影響を 及ぼす重要な要因のひとつでもある。そこで本研究で は，スティグマ集団の成員に見られる否定的評価への 対処方略について, 原因州属研究のパラダイムを用い て検討した。

スティグマ集団の成員が否定的に評価された場合, 能力や努力といった自己の資質不足のほかに，所属集

Correspondence concerning this article should be sent to: Nobuko Asai. Graduate School of Humanities and Social Sciences. Kobe University, Rokkodai-cho, Nada-ku, Kobe 657-8501, Japan (e-mail: nobl113@ fine.ocn.ne.jp)

本論文の研究 1 は, 神戸大学大学院文学研究科平成 13 年度 修士論文の一部をもとに, 再分析・加筆修正したものである。 また, 本研究の一部は, 日本社会心理学会第 42 回, 43 回大会, 及びInternational Symposium on the Socio-Cultural Foundations of Cognition (京都) において発表されている。本論文の 執筆にあたって, 日本学術振興会・科学研究費補助金（基盤研 究 B・\#15330134, 研究代表者：唐沢穣）の補助を受けた。
団への差別が，その原因として知覚される可能性があ る。評価の原因を差別という外的要因に帰属すること で，自己への責任帰属を割り引き，自尊心を維持する ことが可能になると考えられるからである (Crocker \& Major, 1989)。

ところが実際には, 否定的評価の原因は差別に帰属 されにくいことが近年の研究から明らかになっている (Ruggiero \& Taylor, 1997; Schmitt \& Branscombe, 2002b)。このような帰属傾向は “個人的差別知覚の 最小化” (Minimization of Personal Discrimination; 以下，MPD とする）と呼ばれる。MPDは，評価の 原因を差別に帰属したからといって自尊心が維持され ないことを示している。特定の集団に対する差別的な 信念は，人々に広く共有されており，かつ社会システ ムの中に構造的に組み込まれている（Miles，1989; Redpath \& Harvey, 1992)。そのため, 差別帰属は, 所属集団への差別が, 状況（例：時間，場所，課題） を越えて自分自身に影響を与えることの認識を促進 し, 自尊心や統制感に脅威を与えるとともに, 将来の 失敗可能性の予期を生じさせると考えられる。加え て, Schmitt \& Branscombe (2002a) は, 差別への原 因帰属が，自分自身の内に存在する，自己を差別の対 象たらしめている “否定的な集団成員性”への帰属を 
意味することを明らかにしている。これは, 差別帰属 が必ずしも自己への責任帰属を割り引かず，被評価者 の社会的アイデンティティや自尊心に脅威を与えるこ とを示唆する。以上の議論を考慮すると, 差別帰属 は, スティグマ集団の成員の精神的健康を阻害するこ とが示唆される。実際, Kobrynowicz \& Branscombe (1997) やMajor, Quinton, \& McCoy (2002) は, 自 分自身が差別の対象であると知覚するほど, スティグ マ集団の成員の幸福感は低下し, 抑うつ傾向を示すこ とを明らかにしている。これらは, 差別帰属が心理的 コストを伴う帰属方略であることを示唆する。

Schmitt \& Branscombe (2002b) は, この差別帰属に 伴う心理的コストを回避し, 精神的健康を維持しよう とする自己防衛動機が MPD を生起させると主張した (Crosby, 1984 も参照)。

一方, 所属集団に対する差別の明確さが, 否定的評 価の原因帰属に与える影響という視点から, MPDに ついて実験的検討を加えたのが Ruggiero \& Taylor （1997）である。この実験では，女性に文章作成課題 への回答を求め, 採点結果として否定的評価 ( $\mathrm{D}$ 評 定）を与えた。差別の明確さは, 課題の採点者を紹介 する際に，8名の男性採点者に含まれる女性差別的な 人物の数を 8 名 $(100 \%), 6$ 名 $(75 \%), 4$ 名 $(50 \%)$, 2 名 $(25 \%), 0$ 名 $(0 \%)$ と段階的に変化させること で操作した。実験の結果, 採点者がすべて差別的な人 物である 100\%条件では, 評価の原因は差別に帰属さ れたのに対し，女性が差別されるかどうかが不明確な 条件（75\%条件一 $25 \%$ 条件）では, 差別に帰属されに くい（MPDの生起）ことが明らかとなった。さら に, 原因を差別に帰属しない人ほど, 社会次元の状態 自尊心（他者からの受容や承認に伴い短期的に変動す る自尊感情) が高く2, 自己の能力や社会的事象に対 する統制感も高いことが示された。この結果は, MPD が自尊心，及び統制感の維持に寄与することを 示唆する。また, 原因を差別に帰属した程度と, 自己 の内的要因に帰属した程度に, 負の相関関係が認めら れた。このことから Ruggiero \& Taylor (1997) は, 差別帰属に伴う心理的コストから自己を防衛するため には, MPD と同時に原因の内的帰属を行い, 評価に 対する差別の影響を明確に否定することが必要条件と なると主張した。

以上をまとめると，スティグマ集団の成員に扔ける

2 能力次元の状態自尊心（能力や自己の資質に関する自信や 満足度の変化に伴い短期的に変動する自尊感情）は, 差別帰属 の程度と負の相関を持っており,この種の状態自尊心の維持に 差別帰属が寄与している可能性もある。ただし, 差別帰属は, 自己の能力や資質の如何によらず，否定的に評価されるとの認 識をもたらす。したがって, 能力次元の状態自尊心の維持とい う差別帰属に伴う利益よりも，心理的コストの方が，スティグ マ集団の成員に与える心理的影響は強いと考えられる。
否定的評価の原因帰属方略を規定する要因には “差別 帰属に伴う心理的コストからの自己防衛”と“所属集 団に対する差別の明確さ”の二つがあることが示唆さ れる。

しかし, これまでの研究は, MPD が差別㷌属に伴 う心理的コストの回避方略であることを, 自尊心等の 個人差変数と原因㷌属の相関関係からの推定として議 論するにとどまっており, 実験的検討が十分とはいえ ない。また, 先行研究は, MPDの心理的基礎に自己 防衛という自己に関連した過程の存在を仮定しなが ら，MPD が自己に特有の現象であるか否かについて 検証を加えていない（例：Ruggiero \& Taylor, 1997)。 MPD が，スティグマ集団の成員の受けた否定的評価 であれば，たとえそれが他者に対する評価であっても 生じる一般的帰属傾向である可能性も考えられる。そ こで本研究では, 差別㷌属に伴う心理的コストからの 自己防衛とMPD の関連の特定を目指し, 自己以外の 対象が受けた否定的評価の原因帰属を求める比較対象 条件を導入し (研究 1,2), 差別㷌属に伴う心理的コ ストの程度を操作（研究 2）した実験を行った。

\section{研 究 1}

差別帰属に伴う心理的コストから自己を防衛しょう とする過程が，MPDの心理的基礎であることを検証 するために, 自己の受けた否定的評価と内集団他者 （以下，“他者”とする）の受けた否定的評価に関する 原因帰属方略を比較した。所属集団に対する同一視が 強く, 自己と内集団他者を交換可能な存在として認識 するような特殊な場合を除き，他者が個人的に受けた 否定的評価の原因を差別に帰属しても, 自己の自尊心 や統制感に与える否定的影響は比較的小さいであろ う。そのため, 差別帰属を避ける傾向 (MPD) は生 じないと考えられる。これらの議論をもとに, 研究 1 では以下の仮説を検討した。

仮説 1 自己が否定的評価を受けた場合，所属集団 に対する差別の存在が不明確な状況では, 明確に差別 が存在する状況に比べ, 評価の原因を差別に帰属する 程度は低くなる。これに対して, 他者の場合には, こ の傾向は弱まる。

仮説 2 MPD が生起した場合, 評価の原因は被評 価者の内的要因に帰属される。

また, MPD が差別帰属に伴う心理的コストからの 自己防衛動機に基づくならば, 評価の原因帰属と自尊 心の関連について，以下のように予測される。

仮説 3 自己の受けた評価の原因を差別に帰属しな い人ほど, 社会的次元の状態自尊心が高い。一方, 他 者の受けた評価の原因帰属と状態自尊心には関連がな い。 


\section{方 法}

予備調査 予備調査の対象は, 女子大学生 12 名。 まず, 女性差別的な男性と差別的ではない男性を記述 した刺激文を 35 文字程度で各六つ作成した（例：女 性差別的な発言が目立ち, 職場は男の場所と考えてい る)。次に, 各人物を就職試験の面接官と仮定し, 女 性を差別的に評価をすると思うかを1（非常にそう思 う)-7（非常にそう思わない）の7件法で尋ねた。平 均評定值が尺度の中点(4)より有意に小さかった 5 文 を女性差別的な男性（5 文の平均評定値 1.82), 差の なかった 5 文を女性差別的ではない男性（平均評定值 4.83）を示すものとして実験に用いた。

\section{本実験}

参加者 関東地区の私立女子大学の学生 196 名。

実験計画 2 (知覚対象：自己/他者) $\times 3$ (差別の明 確さ：明確あり/不明確/なし) の要因配置で, ともに 参加者間要因とした。

実験手続き 実験には，場面想定法を用いた。実験 は, 複数の講義時間中に女性実験者 1 名が集団一斉法 で実施した。所要時間は約 30 分であった。

最初に, 場面想定のためのシナリオと質問紙を綴じ た冊子を配布した。シナリオでは, 女性主人公が企業 の就職面接を受け，不採用になる場面を 3 ページに分 けて呈示した。1ページ目には面接に至るまでの経緯 と面接方法の説明を，2ページ目には面接官 5 名に関 する情報として予備調查で選定した刺激文を箇条書き 形式で記載した。3ページ目には不採用通知を受け取 る場面を描いた。シナリオは, 実験者の合図で読み進 めるよう求めた。

差別の明確さは, 男性面接官 5 名に含まれる女性差 別的な人物の数を 5 名 (明確あり条件), 3 名 (不明 確条件), 0 名（差別なし条件）と段階的に変化させ, 5 名のうち 1 名が主人公の面接を担当するとの設定に することで操作した。すなわち, 主人公が差別的な男 性に面接を担当される可能性を変動させた。知覚対象 は, 主人公を“あなた”，または“A 子さん”と表記 することで操作した。

シナリオ呈示後, 質問紙への回答を求めた。回答に は, 時間制限を設けなかった。最初に, 不採用の原因 㷌属を求めた。質問項目は, 女性差別への帰属を示す 2 項目（例：面接官の女性差別意識）と, 知覚対象の 内的要因への帰属を示す 4 項目 (例：その業種に必要 な能力が低かった）を含む10項目とし, 各項目を不 採用の原因と思う程度について1（非常にそう思う） -7 (非常にそう思わない) の7件法で祝ねた。続い て, 参加者の状態自尊心を測定した。測定には, Heatherton \& Polivy（1991）の状態自尊心尺度のう ち, 本研究と関連する社会次元 7 項目（例：人の目を
気にする) と能力次元 7 項目（例：自分の能力に自信 がある) を翻案したものを用いた。回答は，1 (非常 にあてはまる)-7 (非常にあてはまらない) の 7 件法 とし, シナリオ場面ではなく, 現在の状態を尋ねた。 状態自尊心尺度は, これまでも場面想定法を用いた研 究で, 実験操作への反応に伴う自尊心の変化を捉える 指標として使用されており, 本研究における自尊心測 定にも適すると考えられた（例：Leary, Haupt, Strausser, \& Chokel, 1998)。さらに, 各原因㷌属項目 が示す原因の所在 (1: 内的一 $7:$ 外的), 統制可能性 (1: 統制可能一7: 不可能), 安定性 (1: 安定一7: 不 安定）を７件法で尋ねた。この質問では, 条件にかか わらずすべての参加者に, 自分自身にとって各原因帰 属項目がどのような心理的意味を持つのかを尋ねた。 最後に，面接官に含まれていた女性差別的な人物数の 記入を求めた。

\section{結果と考察}

社会人学生と回答に不備のあった 6 名を除く, 190 名を分析対象とした (年齢層：18-23 歳, 平均年 齢：19.17 歳, すべて就職活動未経験者)。

操作チェック 質問紙で記入を求めた, 女性差別的 な人物の数を条件間で比較した。 $2 \times 3$ の分散分析を 行った結果, 差別の明確さの主効果のみが認められた $(F(2,184)=247.59, p<.01)$ 。差別明確あり条件 $(M=4.59)$ で最も多くの人数が報告されており, 差 別不明確条件 $(M=2.80)$, 差別なし条件 $(M=$ 1.13）の順に有意に減少していた（Tukey 法 $\alpha=$ .05 ; 以下, すべて同様)。これにより, 差別の明確さ の操作の有効性が確認された。

原因帰属 まず, 原因帰属項目の評定值を, 值が大 きいほど当該の要因に原因を帰属していたことを示す よう変換した。差別帰属に関する 2 項目の相関係数は $.80(p<.01)$ と高く, これらの平均評定值を各参加 者の差別帰属得点とした。また, 内的要因への帰属を 示す 4 項目の信頼性係数は. 70 であり, 4 項目の平均 評定值を個人内帰属得点とした。

原因帰属得点について, 独立変数に参加者内要因と して帰属の種類（以下, 帰属とする: 差別帰属/個人 内帰属）を加えた， $2 \times 3 \times 2$ の分散分析を行った。そ の結果, 差別の明確さの主効果が認められた $(F(2$, $184)=27.07, p<.01)$ 。また, 知覚対象 $\times$ 差別の明確 さ $(F(2,184)=3.09, p<.05)$, 知覚対象 $\times$ 帰属 $(F(1$, $184)=14.20, p<.01)$, 差別の明確さX㷌属 $(F(2$, $84)=70.27, p<.01 ）$ の交互作用が有意であった。し かし, これらの主効果と交互作用は, いずれも知覚対 象 $\times$ 差別の明確さ $\times$ 㷌属の交互作用傾向に規定されて いた $(F(2,184)=2.53, p<.10)$ 。下位検定の結果, 自己条件と他者条件で, ともに差別の明確さ $\times$ 州属の 単純交互作用が認められた $(F(2,184)=44.33, p<$ 
$.01 ; F(2,184)=28.10, p<.01$, Figure 1)。

知覚対象ごとに, さらに下位検定を行った結果, 自 己条件では, 女性が差別されるか否かが不明確な状況 $(M=4.36)$ や差別されていない状況 $(M=2.78)$ よ りも, 明確に差別されている状況 $(M=5.71)$ で, 不 採用の原因を差別に帰属していた。また, 不明確条件 では, 差別なし条件よりも差別帰属の程度が高かった $(F(2,368)=59.16, p<.01)$ 。個人内㷌属の程度には, 差別の明確さの影響が認められなかった（ $F(2$, 368) $=2.06$, $n s ; M=4.56)$ 。

一方, 他者の不採用の原因帰属では, 差別明確あり 条件 $(M=5.32)$ と不明確条件 $(M=5.17)$ で, 差別 帰属の程度に差が認められなかった。また,これら 2 条件では差別なし条件 $(M=3.29)$ よりも, 差別㷌属 の程度が高かった $(F(2,368)=12.13, p<.01)$ 。個人 内㷌属には, 差別の明確さは影響していなかった $(F(2,368)=1.89, n s ; M=4.10)$ 。

以上の分析から, 仮説 1 で予測したように, 所属集 団に対する差別の存在が不明確な状況では, 否定的評 価を受けても，その原因は差別に帰属されにくい （MPD）が，他者が否定的評価を受けた場合，その原 因は差別に帰属されやすいことが明らかとなった。こ のことから，スティグマ集団の成員における否定的評 価の原因帰属方略には, 自己・他者間の判断バイアス が存在することが示唆される。ただし, 自己条件で は, 差別なし条件よりも不明確条件で差別帰属の程度 が高まっており, 先行研究に見られるほど強いMPD が生じていたわけではない。

個人内帰属に関しては, 両知覚対象条件で差別の明 確さにかかわらず, 否定的評価に対して一定レベルの 個人内帰属がなされていた。言い換えると, 差別㷌属 の程度が高かった条件でも，低かった条件でも，同程 度に個人内帰属がなされていた。したがって, MPD と個人内帰属が関連することを予測した仮説 2 は支持 されなかった。

差別帰属と個人内帰属の関連 差別帰属と個人内帰 属の関連を検討するために, 知覚対象ごとに相関分析

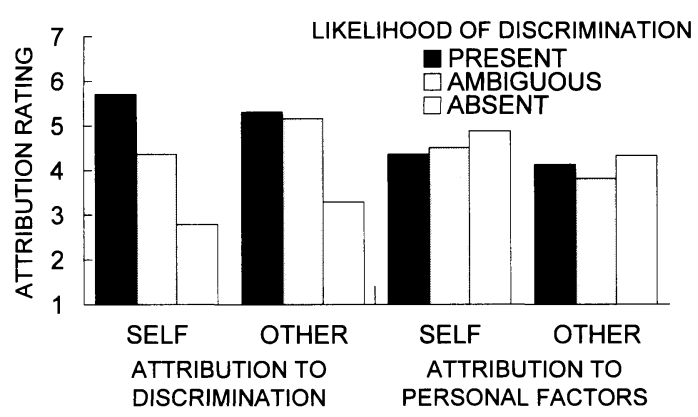

Figure 1. Mean attribution ratings as a function of the target, discrimination likelihood, and the type of attribution.
を行った。その結果, 両知覚対象で, 差別帰属と個人 内帰属の有意な関連は認められなかった $(|r| s<.10$, $n s)$ 。すなわち，相関分析からも仮説 2 は支持されな かった。したがって, MPD と原因の内的帰属は, Ruggiero \& Taylor (1997) が主張したように同時に 生じるものではなく, 独立な関係にあることが示唆さ れる。

差別帰属と個人内帰属の意味 差別帰属と個人内帰 属の心理的意味, 及び原因帰属に伴うコストの差異 を, 原因帰属項目に関する原因の所在と統制可能性, 安定性の評定值から比較検討した。各評定值につい て, 差別㷌属 2 項目と個人内帰属 4 項目の平均評定値 を算出し, 個別に $2 \times 3 \times 2$ の分散分析を行った。その 結果, 原因の所在と統制可能性で, 㷌属の主効果のみ が認められた $(F(1,184)=78.98, p<.01 ; F(1$, $184)=159.71, p<.01)$ 。具体的には, 差別帰属が, 個 人内帰属よりも外的, かつ統制不可能な要因に原因を 帰属することを意味していたことが示された（原因の 所在 差別帰属: $M=4.53$, 個人内㷌属: $M=2.91$, 統制可能性 差別帰属: $M=4.27$, 個人内帰属: $M=$ 3.13)。この結果は, 差別㷌属が, 統制感の喪失とい う心理的コストを伴うことを示唆する (Rotter, 1966)。なお, 安定性に関しては, 条件の有意な効果 は認められなかった。

原因帰属と状態自尊心の関連 状態自尊心尺度の評 定值を，值が大きいほど状態自尊心が高いことを示す ように変換した。その後, 参加者ごとに, 社会次元 7 項目と能力次元 7 項目の平均評定值を算出し, それぞ れを社会次元の状態自尊心得点, 能力次元の状態自尊 心得点とした（Cronbach の $\alpha=.80 ; \alpha=.82) 。$

これらの状態自尊心得点と差別帰属, 及び個人内帰 属の程度について, 知覚対象ごとに相関分析を行っ た。その結果, 自己条件では, 差別帰属と社会次元の 状態自尊心に負の相関傾向が示された $(r=-.20$, $p<.10)$ 。つまり, 自己の不採用の原因を差別に帰属 しない人ほど社会次元の状態自尊心が高かった。これ は, MPD が社会的領域の状態自尊心維持という自己 防衛的な意味を持っている可能性を示す。また，個人 内帰属と, 社会次元と能力次元の両状態自尊心には, 負の相関が認められた $(r=-.39, p<.01 ; r=-.30$, $p<.01)$ 。すなわち, 不採用を自己の内的要因による ものと知覚した人ほど, 状態自尊心が全体的に低かっ た。一方，他者条件では，原因帰属と状態自尊心との 相関に有意なものはなく, 自己防衛と他者に関する原 因㷌属は無関連であることが明らかとなった $(|r| s<$ $.14, n s)$ 。以上は, 仮説 3 と一貫する。

これらの結果を総合すると, 自己が否定的評価を受 けた場合にのみ, 差別帰属に伴う心理的コストからの 自己防衛方略として MPD が生起した結果, 評価の原 因帰属に自己・他者間の判断バイアスが生じたと考え 
られる。

ただし，研究 1 では，原因帰属に伴う心理的コスト を実験的に操作したわけではないため, 自己防衛動機 の生起の有無が評価の原因帰属を規定しているか否か は明確ではない。そこで, 研究 2 では, この問題点を 解消する実験を実施した。

\section{研 究 2}

研究 2 では, 自己防衛動機が評価の原因帰属に与え る影響を検討するために, 評価の原因を州属しても心 理コストが生じず，自己防衛を志向する必要のない場 合を対照条件として設定し, 評価の原因を差別に帰属 する場合との比較検討を行った。具体的には, “所属 集団に対する優遇”によって, 知覚対象が肯定的に評 価された可能性のある場面を取り上げ，評価の原因を 優遇に帰属する程度を測定した。差別帰属と優遇帰属 は, ともに所属集団に対する不公正な扱いに原因を帰 属することを意味するが，人々に与えるその影響は異 なると考えら机る。差別帰属には先述した心理的コス トが伴うが, 優遇帰属にはこのような心理的コストは 生じないであろう (Branscombe, 1998; Postmes, Branscombe, Spears, \& Young, 1999)。したがって, 差別帰属に特有の心理的コストを回避するための方略 として MPD が生起するのであれば, 優遇帰属では, MPD と同様の原因帰属は生じないと予測される。

仮説 1 自己が否定的評価を受けた場合, 所属集団 に対する差別の存在が不明確な状況では, 明確に差別 が存在する状況に比べ, 原因を差別に帰属する程度は 低くなる。一方, 他者の場合には, この傾向は弱ま る。

仮説 2 所属集団が優遇される可能性のある状況で 受けた肯定的評価の原因帰属方略には, 自己と他者の 間の差異は生じない。

さらに, 研究 1 と同様に, 差別帰属と自尊心につい ては以下の関連が存在すると予測できる。

仮説 3 自己の受けた否定的評価の原因を差別に帰 属しない人ほど, 社会次元の状態自尊心が高い。

なお, 仮説 3 を検証する上での対照条件として, 他 者条件の参加者には, 他者の自尊心状態の推測を求 め, 原因㷌属との関連を検討した。他者が受けた評価 の原因帰属と, 推測した他者の状態自尊心は無関連と 予測される。

\section{方 法}

予備調査 予備調査の対象は女子大学生 47 名。ま ず，女性優遇的な男性を記述した刺激文（例：女性が 職場に進出することを歓迎している）を九つ, 差別・ 優遇とは無関連な男性を記述した刺激文（例：郊外に 家を買ったが, 通勤に時間がかかる) を七つ作成し た。次に, 各人物を就職試験の面接官と仮定して, 女
性を差別的，あるいは優遇的に評価すると思うかを 1 (女性差別的)-7 (女性優遇的) の7 件法で尋祇た。 平均評定值が尺度の中点より有意に大きかった 6 文の 中で, より女性優遇的に評価されていた五つを女性優 遇的な男性 (平均評定值 5.40), 中点と差のなかっ た 5 文を女性差別・優遇と無関連な男性（平均評定値 4.03）を示す文章として実験に用いた。女性差別的な 男性には, 研究 1 と同じ刺激文を用いた。

\section{本実験}

参加者 関東地区の私立女子大学の学生 207 名。

実験計画 2(知覚対象: 自己/他者) $\times 2$ (集団の処 遇 : 差別/優遇 $) \times 3$ (差別/優遇の明確さ：明確あり/ 不明確/なし）の要因配置で, すべて参加者間要因で あった。

実験手続き 講義時間中に, 女性実験者 1 名が実験 を実施した。所要時間は約 30 分で, 主な手続きは, 研究 1 と同一であった。以下, 研究 2 で加えた手続き を示す。

1. 集団の処遇の操作: 知覚対象の所属集団が差 別・優遇のいずれを受けるかを操作した。差別条件で は，女性差別的な人物が面接を担当する可能性がある 状況で面接を受け，不採用となるシナリオを呈示し た。優遇条件では，女性優遇的な人物が面接官となる 可能性が存在する状況で面接を受け, 採用となる場面 を与えた。

2. 差別/優遇の明確さの操作: 差別条件では研究 1 と同様の操作を行った。優遇条件では, 女性優遇的な 面接官の数を 5 名中 5 名, 3 名, 0 名とすることで優 遇の明確さの程度を操作した。

3. 質問紙：原因帰属項目のうち, 差別/優遇への 帰属を示す項目は, 研究 1 で使用した 2 項目に“あな た/A 子さんの性別”を加えた 3 項目とした。研究 1 の項目は, 集団の処遇に合わせて表現を変えた（例： 面接官の女性差別(優遇意識)。内的要因への帰属を示 す項目は, 研究 1 で使用した 4 項目に“あなた/A 子 さんの性格”を加えるなどの改変を行った 5 項目とし た。採用/不採用の原因帰属の測定には, 以上の項目 を含む, 計 11 項目を用いた。また, 状態自尊心尺度 について, 自己条件の参加者には, 現在の状態自尊心 を尋ねた。他者条件では, 採用/不採用となった後の 他者の状態自尊心を推測するよう求めた。さらに, 質 問紙の最後の部分では, 面接官に含まれていた女性差 別/優遇的な人物の数の記入を求めた。

\section{結 果}

社会人学生と回答に不備のあった 3 名を除く, 204 名を分析対象とした (年齢層：18-21 歳, 平均年 齢：18.51 歳,すべて就職活動未経験者)。

操作チェック 質問紙で記入を求めた, 女性差別 
的/優遇的な人物数について, $2 \times 2 \times 3$ の分散分析を 行った結果, 差別/優遇の明確さの主効果のみが認め られた $(F(2,192)=70.06, p<.01)$ 。下位検定の結 果, 報告人数は, 差別/優遇明確あり条件 $(M=$ $4.13)$, 差別/優遇不明確条件 $(M=2.95)$, 差別/優遇 なし条件 $(M=1.80)$ の順で有意に減少していた。すな わち, 差別/優遇の明確さの操作は成功したといえる。

評価の原因帰属 研究 1 と同様の方法で, 差別/優 遇帰属得点と個人内帰属得点を算出した (Cronbach の $\alpha=.83 ; \alpha=66)^{3}$ 。原因帰属得点について, 独立変 数に参加者内要因として䚻属の種類（差別・優遇㷌 属/個人内㷌属）を加えた $2 \times 2 \times 3 \times 2$ の分散分析を行 ったところ, 差別/優遇の明確さと帰属の主効果が認 められた $(F(2,192)=32.52, p<.01 ; F(1,192)=$ $22.21, p<.01)$ 。また, 集団の処遇 $\times$ 差別/優遇の明確 さ $(F(2,192)=3.64, p<.05)$, 差別/優遇の明確さ $\times$ 㷌属 $(F(2,192)=68.34, p<.01)$ ，集団の処遇 $\times$ 帰属 $(F(1,192)=23.79, p<.01)$, 知覚対象 $\times$ 集団の処 遇 $\times$ 㷌属 $(F(1,192)=4.90, p<.05)$ の交互作用が有 意であった。しかし, これらの効果は, 知覚対象 $\times$ 集 団の処遇 $\times$ 差別/優遇の明確さ $\times$ 帰属の交互作用に規 定されていた $(F(2,192)=8.07, p<.01)$ 。下位検定 の結果, 差別条件と優遇条件で, 知覚対象 $\times$ 差別/優 遇の明確さ $\times$ 帰属の単純交互作用が認められた $(F(2$, 192) $=4.54, p<.05 ; F(2,192)=3.60, p<.05$, Figure 2)。以下，集団の処遇ごとに分析結果を記す。

差別条件 自己条件と他者条件で, 差別/優遇の明 確さ×帰属の単純交互作用が認められた $(F(2$, $192)=18.32, p<.01 ; F(2,192)=16.04, p<.01)$ 。自 己条件では，女性が明確に差別されている状況 $(M=5.89)$ で, 差別の存在が不明確な状況 $(M=$ 4.65）や差別のない状況 $(M=3.90)$ よりも, 不採用

3 本研究では, 差別帰属と優遇帰属を集団に対する不公正な 扱いへの帰属を表す一つの指標とみなした。なお, 原因帰属項 目について，集団の処遇ごとに因子分析を行い，差別条件と優 遇条件で同様の因子構造が保たれていることを確認した。差別 㷌属項目のみの信頼性係数は.78であり，優遇帰属項目では .85 であった。
の原因を差別に帰属していた。また，後者 2 条件の差 別帰属の程度には差が見られず，差別の存在が不明確 な状況では MPD が生じていた $(F(2,384)=20.02$, $p<.01)$ 。個人内帰属に関しては, 差別/優遇の明確さ の影響傾向が示されたが，条件間の多重比較からは有 意な差は検出されなかった $(F(2,192)=2.36, p<$ .10)。

一方, 他者条件では, 自己条件と異なり, 差別明確 あり条件 $(M=5.57)$ と不明確条件 $(M=5.77)$ で同 程度に不採用の原因を差別に帰属していることが示さ れた。また,これらの 2 条件では, 差別なし条件 $(M=3.96)$ よりも差別㷌属の程度が高かった（ $F(2$, $384)=17.55, p<.01)$ 。個人内㷌属では, 差別/優遇の 明確さの影響が認められなかった $(F(2,192)=2.32$, $n s ; M=4.95$ )。

以上の分析から，自己条件でのみ MPD が生起する ことが明らかとなり，仮説 1 は支持された。また，個 人内帰属に関する結果は, 研究 1 と一貫していた。さ らに，差別㷌属と個人内㷌属の関連を，知覚対象と集 団の処遇からなる 4 条件の条件ごとに相関分析から検 討した結果, 研究 1 と同様に, 有意な関連は一切認め られなかった $(|r| s<.14, n s)$ 。すなわち, MPD が生 起した場合，同時に原因の内的帰属が生じるとの Ruggiero \& Taylor（1997）の主張は支持されず，こ のような帰属傾向がスティグマ集団の成員において一 般的ではないことが示された。

優遇条件 自己条件と他者条件で, 差別/優遇の明 確さX帰属の単純交互作用が認められた $(F(2$, $192)=22.47, p<.01 ; F(2,194)=20.73, p<.01)$ 。自 己条件では, 優遇の存在が不明確な状況 $(M=5.40)$

で，すでに女性が明確に優遇されている状況（ $M=$ 5.55）と同程度に採用の原因を女性優遇に帰属してい た。また，以上の条件では，優遇されていない状況 $(M=2.98)$ よりも優遇㷌属の程度が高かった（ $F(2$, $384)=42.09, p<.01)$ 。個人内帰属には, 差別/優遇の 明確さは影響していなかった $(F<1 ; M=5.24)$ 。

これに対して，他者条件では，優遇明確あり条件 $(M=5.57)$ で，不明確条件 $(M=4.33)$ よりも，評

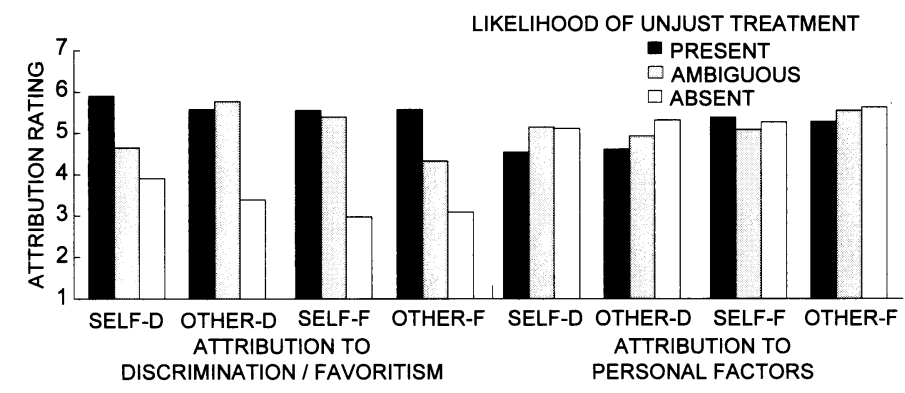

Figure 2. Mean attribution ratings as a function of the target, outcome, unjust treatment, and the type of attribution.

Note. $-\mathrm{D}=$ Discrimination condition, $-\mathrm{F}=$ Favoritism condition. 
価の原因を優遇に帰属していた。またここれらの条件 では優遇なし条件 $(M=3.10)$ よりも，優遇帰属の程 度が高かった $(F(2,384)=11.22, p<.01)$ 。個人内㷌 属には, 差別/優遇の明確さは影響していなかった $(F<1 ; M=5.48)$ 。

このように，自己の受けた肯定的評価の方が，他者 の場合よりも, 評価の原因は所属集団への優遇に帰属 されやすかった。すなわち，仮説 2 は支持されなかっ た。

原因帰属と状態自尊心の関連 社会次元と能力次元 の状態自尊心得点を研究 1 と同様に算出した (Cronbach $の ~ \alpha=.80 ; \alpha=.82$ )。続いて, 各状態自尊 心得点と差別/優遇帰属, 及び個人内帰属の程度につ いて, 知覚対象と集団の処遇からなる四つの条件ごと に相関分析を行った。差別条件では，自己の不採用の 原因を差別に帰属した程度と社会次元の状態自尊心の 間にのみ有意な負の相関が認められ，差別に原因帰属 しない人ほど, 社会次元の状態自尊心が高いとの関係 が示された $(r=-.35, p<.01)$ 。すなわち, 仮説 3 は 支持され，MPD が自己防衛的な意味を保持している ことが示唆された。また, 他者の不採用の原因帰属と 推定した他者の状態自尊心は無関連であった $(|r| s<$ $.11, n s)$ 。また, 優遇条件では, 有意な相関が認めら れなかった $(|r| s<.20, n s)$ 。

\section{考 察}

分析の結果, 所属集団への差別の存在が不明確な状 況で, 自己が否定的評価を受けた場合には MPD が生 起し，他者の場合には差別に原因帰属されることが明 らかになった。つまり, 自己と他者では, 差別帰属が 喚起されるに至る差別の明確さの基準が異なってお り, 研究 1 と一貫して, 否定的評価の原因帰属方略に 自己・他者間の判断バイアスが認められた。このこと は，スティグマ集団の成員であれば，誰の失敗であっ ても差別帰属が差し控えられるわけではなく, MPD が自己に特有の現象であることを示唆する。また, 研 究 2 からも, MPD が状態自尊心の維持という自己防 衛的な意味を持つ可能性が示された。

優遇条件をみると，仮説 2 に反して，自己と他者の 間で肯定的評価の原因帰属方略に差異が認められた。 そこで, 自己に関する原因帰属にのみ注目すると, 優 遇条件では差別条件と異なり, 所属集団への優遇の存 在が不明確な状況でも, 明確に優遇されている状況と 同程度に，優遇帰属がなされていた。つまり，自己の 受けた評価の原因は, 差別には帰属されにくいが, 優 遇には帰属されやすかった。この結果は, MPDが差 別帰属に伴う心理的コストの回避を目的した帰属方略 であるとの知見を支持する (Schmitt \& Branscombe, 2002b)。

他者の受けた否定的評価の原因は, 研究 1 と一貫し
て，差別に帰属されやすいことが示された。その一方 で, 肯定的評価の原因は優遇に帰属されにくかった。 このような結果が得られた要因は, 複数存在するであ ろう。例えば，参加者が他者に関して原因帰属を行う 際に，他者像としてスティグマ集団の典型的成員像 （差別されやすく，優遇を受けにくい人物像）を用い ていた可能性があげられる。しかし，本研究は，他者 に関する原因帰属を検討するための実験計画ではな い。したがって,この点の検討には, 新たな研究を行 う必要がある。

ところで, 所属集団に対する優遇の認識にも, 特有 の心理的コストが存在するとの議論がある。例えば, 優遇を所属集団へのひいきと捉えた場合，集団的な罪 悪感が生起する可能性がある。また，あえて優遇する 必要があるほど所属集団の社会的地位が低いと知覚さ れれば，優遇はかえって所属集団の劣位を顕著にし， 自尊心を害するであろう (Boxill， 1992; Heilman \& Alcott, 2001)。しかし, 本研究の結果を見ると, 自己 の受けた肯定的評価は, 所属集団への優遇に帰属され やすかった。また優遇帰属と状態自尊心の間には負の 関連は認められなかった。これらは, 優遇帰属には心 理的コストが関与していないことを示唆する。さら に, 自己条件で優遇帰属がなされやすかったことは, 自分自身が肯定的な集団成員性を保持していることの 積極的な認識, すなわち社会的アイデンティティや自 尊心の高揚を目的とした原因帰属方略がとられていた ことを示す結果とも解釈できる。ただし，所属集団へ の優遇の認識が, スティグマ集団の成員に与える心理 的影響については, 一貫した研究結果が得られていな い(Branscombe, 1998; Heilman \& Alcott, 2001)。優 遇への原因帰属を深く理解するには, 優遇の認識が持 つ心理的意味について詳しく検討する必要がある。

\section{全体的考察}

本研究の結果は, 女性への就職差別場面において MPD が生じることを示している。すなわち, 所属集 団に対する差別の存在が不明確な状況で個人的に否定 的評価を受けても，その原因は集団に対する差別には 帰属されにくいことが明らかになった。そして, MPD は自己防衛的な意味を持つ㷌属方略であること が示唆された。また, MPDが, 自己が否定的評価を 受けた場合に特有の現象であり，他者が否定的に評価 された場合や所属集団が優遇されている状況では生起 しないことも明らかになった。

以上を総合すると“差別によって自分自身が否定的 に評価されても，評価に差別が影響したという事実を 否定して，MPD を生起させ，社会的アイデンティテ イや状態自尊心，統制感を維持する”という対処過程 がスティグマ集団の成員に存在することが示唆され る。また, このような差別の知覚, 対処過程が特に働 
きやすいのは，所属集団が差別されているか否かが不 明確な状況といえる。今日の社会では，特定の集団を 差別することは社会的な規範に反するため, 差別が明 確な形でなされることは少なくなった。スティグマ集 団の成員が, MPD という原因帰属方略を用いる状況 は拡大していると考えられる。

ただし，本研究で用いた場面想定法は，現実場面と 比べて, 実験参加者の心理状態に与える影響が弱く, 諸変数の関係を考察するのには限界がある。今後は, 実験室実験や調査研究も併用し, MPD の生起過程を 検討することが不可欠である。

本研究からは，MPD はスティグマ集団に所属する 個々の成員の自尊心や精神的健康の維持に繫がる自己 防衛的な原因帰属方略であることが示された。それで は，MPD は社会やスティグマ集団全体にどのような 影響を与えるのであろうか。Ruggiero \& Taylor （1997）は, MPDが生起した場合, 否定的評価と差 別は無関連であると認識されるため, 評価の不当性は 主張されず，即時的な差別への対抗行動は行われにく くなると指摘している。また，自分自身に対する差別 の影響を過少視することによって, 所属集団への差別 が注目すべき深刻な問題であるとの意識は弱まるであ ろう。その結果, 差別に対する集団的な対抗行動への 積極性も低下し，社会に㧈ける差別は維持されやすく なると予測される（Dion＆Kawakami, 1996）。

以上の議論を総合すると, MPD は, 所属集団に対 する差別の維持, すなわち個人の精神的健康に脅威を 与える環境の維持をもたらすという側面を持つことが 示唆される。この議論を踏まえると, MPD は, 最善 の原因帰属方略と位置づけることはできない。むし ろ, MPD を低減させることこそが, 差別の解消と, スティグマ集団の成員の安定した精神的健康の確立に 繋がると予測されるのである。今後はこの点に注目 し，スティグマ集団の成員における差別の知覚・対処 過程が社会やスティグマ集団に与える影響についても 検討する必要がある。

\section{引用文献}

Boxill, B. R. (1992). Blacks and social justice. Revised ed. Lanham, MD: Rowman \& Littlefield.

Branscombe, N. R. (1998). Thinking about one's gender group's privileges or disadvantages: Consequences for well-being in women and men. British Journal of Social Psychology, 37, 167-184.

Crocker, J., \& Major, B. (1989). Social stigma and self-esteem: The self-protective properties of stigma. Psychological Review, 96, 608-630.

Crosby, F. (1984). The denial of personal discrimination. American Behavioral Scientist, 27, 371-386.

Dion, K. L., \& Kawakami, K. (1996). Ethnicity and perceived discrimination in Toronto: Another look the personal/group discrimination discrepancy. Canadian Journal of Behavioral Science, 28, 203-213.

Heatherton, T. F., \& Polivy, J. (1991). Development and validation of scale for measuring state selfesteem. Journal of Personality and Social Psychology, 60, 895-910.

Heilman, M. E., \& Alcott, V. B. (2001). What I think you think of me: Women's reactions to being viewed as beneficiaries of preferential selection. Journal of Applied Psychology, 86, 574-582.

Kobrynowicz, D., \& Branscombe, N. R. (1997). Who considers themselves victims of discrimination?: Individual difference predictors of perceived gender discrimination in women and men. Psychology of Women Quarterly, 21, 347-363.

Leary, M. R., Haupt, A. L., Strausser, K. S., \& Chokel, J. T. (1998). Calibrating the sociometer: The relationship between interpersonal appraisals and the state self-esteem. Journal of Personality \& Social Psychology, 74, 1290-1299.

Major, B., Quinton, W. J., \& McCoy, S. K. (2002). Antecedents and consequences of attributions to discrimination: Theoretical and empirical advances. In M. P. Zanna (Ed.), Advances in experimental social psychology. Vol.34. San Diego: Academic Press. pp. 251-330.

Miles, R. (1989). Racism. London: Routledge.

Postmes, T., Branscombe, N. R., Spears, R., \& Young, H. (1999). Comparative process in personal and group judgments: Resolving the discrepancy. Journal of Personality and Social Psychology, 76, 320-338.

Redpath, R., \& Harvey, B. (1992). Young people's intensions to enter higher education. London: HMSO.

Rotter, J. B. (1966). Generalized expectancies for internal versus external locus of control of reinforcement. Psychological Monographs. No. 609. (Vol. 80, No. 1)

Ruggiero, K. M., \& Taylor, D. M. (1997). Why minority group members perceive or not perceive the discrimination that confronts them: The role of self-esteem and perceived control. Journal of Personality and Social Psychology, 72, 373-389.

Schmitt, M. T., \& Branscombe, N. R. (2002a). The internal and external causal loci of attributions to prejudice. Personality and Social Psychology Bulletin, 28, 620-628.

Schmitt, M. T., \& Branscombe, N. R. (2002b). The meaning and consequences of perceived discrimination in disadvantaged and privileged social groups. In W. Stroebe \& M. Hewstone (Eds.), European Review of Social Psychology. Vol. 12. England: Wiley. pp. 167-199.

- 2003.12. 22 受稿, 2006. 5.7 受理—— 